This is an electronic reprint of the original article. This reprint may differ from the original in pagination and typographic detail.

Author(s): Rautiainen, Antti; Urquía-Grande, Elena; Muñoz-Colomina, Clara

Title: $\quad$ Institutional Logics in Police Performance Indicator Development : A Comparative Case Study of Spain and Finland

Year: $\quad 2017$

Version:

Please cite the original version:

Rautiainen, A., Urquía-Grande, E., \& Muñoz-Colomina, C. (2017). Institutional Logics in Police Performance Indicator Development : A Comparative Case Study of Spain and Finland. European Accounting Review, 26(2), 165-191.

https://doi.org/10.1080/09638180.2015.1120412

All material supplied via JYX is protected by copyright and other intellectual property rights, and duplication or sale of all or part of any of the repository collections is not permitted, except that material may be duplicated by you for your research use or educational purposes in electronic or print form. You must obtain permission for any other use. Electronic or print copies may not be offered, whether for sale or otherwise to anyone who is not an authorised user. 


\title{
Institutional logics in police performance indicator development: a comparative case study of Spain and Finland
}

\author{
Antti Rautiainen*, Elena Urquía-Grande ${ }^{\#} \&$ Clara Muñoz-Colomina ${ }^{\#}$
}

\begin{abstract}
Police performance is not easily measurable and the organization and circumstances of police work vary among European countries. Further, police work is surrounded by multiple pressures to make it both economical and effective. Consequently, there are multiple institutional logics in decision-making which may affect the selection and the use of police key performance indicators (KPIs). The KPI selection and use processes reflect the institutional logics, though KPI use may also sometimes influence the institutional logics of police work. In this study we analyse the KPIs and institutional logics in police work in Finland and Spain. A comparative case research approach is used in order to highlight the differences in institutional logic emphases and in circumstances. Data from semi-structured interviews, internet reports, project work and discussions are used. Both similarities and differences in the KPIs and in the institutional logic emphasis are found between the Finnish and Spanish police. Understanding the partly general and partly locally constructed nature of institutional logics may facilitate the development of police work performance measurement. We also suggest ways of coping with multiple institutional logics. For example, risk-analyses and selecting KPIs against the current institutional logic may facilitate organizational developments.
\end{abstract}

Keywords: performance measurement, key performance indicators, police services, institutional logics, Finland, Spain.

* Antti Rautiainen, PhD, Professor (Feb-Aug 2017), Jyväskylä University School of Business and Economics, Jyväskylä, Finland. Corresponding author, antti.i.rautiainen@jyu.fi

\# Elena Urquía-Grande, PhD, Associate Professor, Faculty of Economics and Business, Complutense University Madrid, Spain

* Clara Muñoz-Colomina, PhD, Associate Professor, Faculty of Economics and Business, Complutense University Madrid, Spain 


\section{Institutional logics in police performance indicator development: a comparative case study of Spain and Finland}

\section{Introduction}

Performance measurement (PM) tools and key performance indicators (KPIs) have been introduced to help managers in police work. More generally, the New Public Management (NPM) trend has encouraged public organizations to measure their outcomes in relation to the interests of the citizen (Hood, 1995, Lapsley, 2008; ter Bogt, Budding, Groot and van Helden, 2010). PM tools serve as tools for improving processes, for diminishing organizational risks and for prioritizing efforts (Kaplan, 2001; Lapsley, 2009; Power, 2004). However, PM efforts may lead to more administrative work and distract organizational attention from operational processes (Olson, Humphrey and Guthrie, 2001).

Public sector accounting and PM have been widely studied, and, despite EU regulation (harmonization) and the NPM trend, differences among European countries have been found (Boyne, 2003; Carmona and Grönlund, 2003; Carvalho, Fernandes, Lambert and Lapsley, 2006; Marques, Ribeiro and Scapens, 2011; Olson, Guthrie and Humphrey, 1998). The various stakeholders of public organizations have multiple aims and interests, which create multiple institutional pressures for selecting and using KPIs. Further, there may be various professionally and organizationally developed institutional logics, i.e. specific decision-making principles, in the processes of selecting and using KPIs within organizations (see Hyvönen, Järvinen, Pellinen and Rahko, 2009; Lapsley, 2008; 2009; Modell, 2009; Reay and Hinings, 2009; Rautiainen and Järvenpää, 2012).

Institutional logic is a guiding decision-making principle in an organization or in a group (e.g. Lounsbury, 2008). Multiple institutional logics may exist in an organization but usually one logic is prominent, for example a financial emphasis on decision-making or a professional one (Reay and Hinings, 2009). Currently police organizations are under strong financial pressure as well as pressure to be as effective as possible, a combination of facts which suggests there are multiple relatively strong institutional logics present at the same time (see Rautiainen and Järvenpää, 2012; Reay and Hinings, 2009). Situations with multiple strong institutional logics are usually short phases, but may persist if there are strong organizational interests that force co-operation (Reay and Hinings, 2009). There has been little accounting research, however, that has focused in a comparative international approach on 'accounting for the police' or, more importantly, on the similarity and dynamics of institutional logics and KPIs. Further, it is not known how the institutional logics affect the selection and use of KPIs, and how multiple co-existing institutional logics are coped with in police work, especially in European countries that have different police work organization structure and different cultural backgrounds. Therefore, the aim of this comparative case research is to analyse the links between institutional logics and KPIs as well as suggest ways of coping with multiple institutional logics in the police work of two European countries (in Finland and Spain). 
Police services create collective security and may involve the use of the power of the state over individuals (see Hood and Miller, 2009). The general duties of the police include defending public security, maintaining order and ensuring compliance with the law. In more detail, however, the effects of police work are not easily measurable, even though KPIs are increasingly used in police services in Europe (Collier, 2006; Carmona and Grönlund, 2003; Wisniewski and Dickson, 2001). For example, there are different strategies for police service provision (e.g. proactive or reactive) and not all crimes are the same. Further, Carvalho et al. (2006) noted differences in the design, selection and use of KPIs in the UK and Portugal fire services, some of which might be attributed to differences in national culture or the prominent institutional logics among these northern and southern European countries.

There are differences also in the police work organization and focus areas among European countries. For example, in Spain the Local Police operates under a municipal organization that is separate from the National Police and has a reporting and KPI focus on three operational areas: 1) Citizen Security and Harmony, which prevents and investigates crimes and takes care of surveillance; 2) Traffic Security, which deals with road safety and the mobility of people and vehicles; and 3) Judiciary Police, which handles complaints, gender violence, and prepares traffic accident reports. In Finland, on the other hand, there is only one national police organization with local offices with reporting and KPI focus on: 1) Crime investigation; 2) Surveillance of traffic and security; 3) Licence service functions, such as issuing passports; and 4) Administration. However, it is not clear if these differences are a reflection of differences among the institutional logics, or how KPIs are selected and used in police PM under differing institutional logic emphases.

The different national cultures and idiosyncrasies may hinder the comparability of KPIs, but offer an interesting field for comparative analysis. In particular, KPIs and institutional logics may differ among northern and southern European countries (Carvalho et al., 2006). Therefore, in this paper we take 'polar opposites' and analyse police work in Finland (a Nordic country with about 5 million inhabitants) and in Spain (a Southern European country with about 46 million inhabitants). This comparative case setting facilitates the observation of potential similarities and differences in KPI selection and use, and in the institutional logics of police work. Our research questions are: 1) Are there differences in the institutional logics of police work in Spain and in Finland? 2) How do the potential differences in institutional logics affect the processes of KPI selection and KPI use in Finnish and Spanish police work?

Based on Spanish pilot project experiences, discussions, interviews, Finnish and Spanish police KPIs, annual reports and other texts, we argue that different institutional logics in police work shape processes of KPI design and use, and vice versa. We reveal national differences and suggest how institutional logics affect KPI selection and use in police organizations. This paper contributes to the public sector management accounting literature by elaborating discussions on institutional logics and KPIs, for example by stressing the importance of a common goal or an accepted decision-aid system in managing the multiple institutional logics. Further, we categorize the institutional logics 
as having several possible emphases, thereby contributing to a detailed view of multiple institutional logics (cf. Rautiainen and Järvenpää, 2012; Reay and Hinings, 2009).

This paper is structured as follows. The next section discusses institutional logics and the development of KPIs in the public sector. Then the methodology and the Spanish and Finnish cases are analysed; we first introduce the KPIs published on the internet and then, based on interviews and discussions, we analyse the institutional logics. In the discussion section the institutional logics of police work are analysed in more detail. Finally, conclusions are drawn and future lines of research are identified.

\section{Institutional logics and KPIs in the public sector}

\subsection{Multiple institutional logics and KPIs}

Institutional logic is a socially constructed guiding decision-making principle for most organizational actors in an organization or in a group (Lounsbury, 2008; ter Bogt and Scapens, 2009; Thornton and Ocasio, 1999). Institutional logics are based not only on legal and other professional norms, but also on the routine behaviour of organizational actors in a case context (Rautiainen and Järvenpää, 2012; Reay and Hinings, 2009). Besides explicit decision-making rationales, such as efficient-choice, institutional logic also includes the subtle, even tacit areas of behaviour which Bourdieu (1990) calls the logic of practice1. However, multiple institutional logics may co-exist in an organization because there are several organizational actor types, organizational levels, cultures, ideologies and interest groups - in short, because there are several institutional pressures for operating and making decisions in a certain way (see Hopper and Major, 2007; Kurunmäki, 2004; Meyer, 1996; Oliver, 1992).

With regard to KPI selection, there are firstly institutional pressures outside the organization, such as legislative or professional requirements, which affect what KPIs are considered necessary or relevant (see DiMaggio and Powell, 1983). Further, there may be different institutional logics among the decision-maker groups selecting the KPIs (Reay and Hinings, 2009). However, depending on the institutional logics within the organization, PM rules and KPIs may be responded to in different ways, a factor which tends to lead to differing use of KPIs among organizations (see Oliver, 1991; Lukka, 2007). For example there may be either financial or professional emphasis in decisionmaking and in the use of KPIs (Reay and Hinings, 2009). Further, political, administrative and social considerations may affect the selection and use of KPIs (Järvinen, 2006; Northcott and Llewellyn, 2003; Oliver, 1992).

1 Wittgenstein (1963, p. 85e, paragraph 217) notes that when explicit justifications (decision-making rationales) for following a rule have run out, there is only the tacit area of taken-for-granted (i.e. institutionalized) ways of practical behaviour left: 'This is simply what I do'. Bourdieu (1990, p. 11) notes that 'logic of practice can only be grasped through constructs which destroy it' [it is no longer tacit and the concept may be inaccurate]. However, by making the institutional logics in police work visible we may facilitate learning and improve managerial decisions, performance and its predictability. The different institutional logics of police work are for example based on the different education, interests and priorities of police officers, managers, politicians and other stakeholders and can affect KPI selection and use. 
In the European police context, legislative and professional pressures may be relatively similar because of EU harmonization efforts and similarities of crime fighting duties among countries. However, because of national and organizational idiosyncrasies, the prominence or emphasis of different institutional logics (or decision-making rationales) may differ, leading to different KPI use. Further, emphasis on certain KPIs may reciprocally either amplify or preclude the use of certain institutional logics.

The types of different institutional logics discussed in earlier literature can be categorized as: 1) financial logic, which is a managerial (business-like or NPM style) decisionmaking logic in the public sector, focused on budgets and measurements; 2) operational logic, such as medical professional decision-making logic reflecting the ethics and codes of conduct in that profession, often paying little attention to the financial implications of decisions; and 3) administrative logic, stressing rules and procedures, often intended to avoid risks and retain the status quo (see Burns and Scapens, 2000; Burns and Vaivio, 2001; Kurunmäki, 2004; Lapsley, 2009; Lounsbury, 2008; Rautiainen and Järvenpää, 2012; Reay and Hinings, 2009). These three institutional logics found in earlier literature seem rather general so that they may be found in many organizations; they reflect, for example, the current financial and professional pressures on police work. However, in more detail, institutional logics are socially constructed and develop locally; there may be different case-specific institutional logics emphases and differing conflicts (amount of non-alignment) among the multiple institutional logics (see Lounsbury, 2008; Rautiainen and Järvenpää, 2012; Reay and Hinings, 2009). Thus different institutional logics may be prominent in our case organizations or there may be different emphases or categories of institutional logics, which may affect the KPI selection and use processes in the case organizations.

Organizations have several ways to cope with multiple co-existing institutional pressures and logics (e.g. Järvinen, 2006; Meyer and Rowan, 1977; Oliver, 1991, 1992). Rautiainen and Järvenpää (2012) suggest that under multiple institutional logics the responses to institutional pressures are indistinct and entangled, suggesting some manipulation of KPIs. The problems of public sector KPI selection and use presented in earlier accounting studies can be considered in parallel to the responses to pressures noted by Oliver (1991), such as acquiescence (compliance), compromise, avoidance, defiance and manipulation:

- Measuring only the easy things (e.g. Carmona and Grönlund, 2003), indicating aspects of compliance but also avoidance and manipulation;

- PM is considered too difficult (e.g. Lapsley, 2008, 2009), indicating compromise and avoidance;

- Lack of good KPIs and PM data (often a genuine reason, see e.g. Carmona and Grönlund, 2003, but may also represent avoidance);

- PM as a legitimacy threat (e.g. Northcott and Llewellyn, 2003), if actors find they are not in line with PM requirements they may defy PM or manipulate the KPIs.

- Either financial or operational institutional logic (e.g. Rautiainen and Järvenpää, 2012), compliance to a certain rules, but ignoring some KPIs and areas of operations.

In order to cope with these problems of KPI selection and use, multidimensional control systems have been suggested for the public sector (e.g. Kaplan 2001; Modell, 2009). 
Further, there is research on balancing KPIs and understanding their legitimacy (e.g. Norreklit, 2000; Lapsley, 2009), but not so much in the field of police work. The institutional logics may emphasize certain responses and affect organizational behaviour and the ways of selecting and using KPIs. Further, KPIs may be used in an enabling way (allowing flexibility and development) or in a constraining way (suppressing creativity), though these ways do not exclude one another (Tessier and Otley, 2012).

When multiple institutional logics exist, a financial logic emphasis may lead to selecting and using KPIs on costs and budgets, and administrative logic emphasis may lead to KPIs being selected and used mainly as legitimating tools (Reay and Hinings, 2009; Rautiainen and Järvenpää, 2012). In practice, however, the interplay between institutional logics and KPIs is not clear: some KPI researchers have defended KPI use for benchmarking but taken benchmarking as a technique for dealing with legitimacy (Ammons et al., 2001; Ammons and Rivenbark, 2008; Bowerman, 1995, 2002; Dorsch, and Yasin, 1998; Higgins et al., 2004; Hinton et al., 2000; Tillema, 2010). Further, multiple KPIs may be used in order for the PM and reporting to be relevant for the various stakeholders, and at the same time to manage the multiple institutional logics. Consequently there are authors who stress KPI design in order to align the tactical and strategic level reporting and planning (e.g. Brignall, 1993; Boland and Fowler, 2000; Boyne et al., 2010; Dalehite, 2008; Irwin, 2002; Jones, 2004; McAteer and Orr, 2006). Furthermore there are authors, who have seen KPI frameworks as tools that help local entities to change, for example towards continuous improvement (Batac and Carassus, 2009; Caiden, 2006; Hoque, 2005; Kloot, 1997; Kloot and Martin, 2000; Light, 1997; Rashman and Radnor, 2005). Finally there has also been criticism of NPM and KPIs that urges researchers to go beyond classic NPM, towards risk-analyses and strategically focused 'post-NPM' KPIs, perhaps thereby managing the multiple institutional logics within organizations (Lapsley, 2009; Lodge and Gill, 2011; Reay and Hinings, 2009).

Reay and Hinings (2009) suggest that the multiple conflicting institutional logics can be managed by 1 ) differentiating professional (e.g. medical) and other decisions; 2) seeking informal input from several sources; 3) working together against a common threat; and 4) innovating as an experiment in certain areas (e.g. in local sites). Rautiainen and Järvenpää (2012) note that co-operation for a common general (or global) idea such as efficiency (whatever it means to different actors) allows conflicting institutional logics in organizations to be managed. The motivation to co-operate may for example come from material interests, coercion or fear, network bonds, local contracts (rules and routines) and professional ethics (e.g. Marques et al. 2011).

In a public environment with several institutional logics, a flexible control system in line with the most important logics might be advisable (Carmona and Grönlund, 2003; Tessier and Otley, 2012). However, too many subjective performance measures may lead to a confusion of goals and to less meaningful, non-differentiating PM (Moers 2005). Further, Olson et al. (2001) see a risk that PM and administrative evaluations take resources away from operational work. Earlier public sector KPI research has noted that the initial KPI selection is often made along the lines of the Balanced Scorecard (BSC) defined by Kaplan and Norton (1992, see e.g. Klingner, 2006; McAdam and Walker, 2003; 
Quinlivan, 2000; Tönnisson, 2004). However, the KPI use is often adjusted for political or legitimacy reasons to the managers' or politicians' will to measure only some suitable aspects of performance (Carmona and Grönlund, 2003; Johnsen, 2005; Muñoz et al., 2006; Navarro et al., 2008; Northcott and Llewellyn, 2003; Norverto et al., 2000; Radnor and McGuire, 2004; Wilson, 2004). Thus the actual use of accounting and PM information varies among countries, organizations and cultures (Adcroft and Willis, 2005; Arnaboldi and Lapsley, 2004; Batac and Carassus, 2009; Boyne, 2003; Carmona and Grönlund, 2003; Carvalho, et al., 2006; Radnor and McGuire, 2004; Verbeeten, 2011; Vinnari and Näsi 2008; Wiesel et al., 2011; Wilson, 2004).

\subsection{Earlier research on police work KPIs}

In the UK police sector, Wisniewski and Dickson (2001) assess the applicability of BSC by illustrating how BSC was used in Scotland as a part of a strategic policing initiative. They conclude that cultural issues need to be considered when a PM system is designed, in order to provide the system with links to overall strategy and performance. Some of the PM design steps can be inconsistent with the existing police culture (or in terms of this study institutional logic) even if, as a whole, the PM system is considered a success (ibid.). Further, Loveday (2005) noted how the KPIs selected also facilitated the UK Police Reform in 2004, by aligning aspects of strategy and PM. This suggests that KPIs may have an effect on the institutional logics. In addition, Collier (2006) concludes that English police PM is also a political issue and subject to continuously changing initiatives that may reduce long term improvement in police work. Instead, consistent priorities (including a focus on citizens and a time frame of at least three years) in policing plans might improve the efficiency in the use of resources and assist in understanding the cause and effect relationship between policy interventions and outcomes (ibid.).

In the context of Nordic Europe, Elefalk (2001) describes a total quality management initiative in the Swedish police, where several KPIs and the BSC approach was used. Considering police work PM in Sweden, Carmona and Grönlund (2003) find that easy-tomeasure indicators were focused on while other important areas of police work were left behind. However, despite active research on public sector PM (e.g. Lapsley 2008, 2009; Modell, 2004), KPIs and institutional logics of police work have not been analysed comparatively in Europe.

In the context of Southern Europe relatively little has been published on police services. Diez et al. (2002) point out that even though a multi-indicator (balanced) view is usable for assessing police work, some areas may be more important than others, making the balancing difficult. Even less research has been made comparing the NPM experiences in citizen security services of two or more countries. Carvalho, et al. (2006) compared the public Fire Services in the UK and Portugal. Despite similar work and institutional pressures (suggesting similarity of KPIs) arising from the EU context, Carvalho et al. (2006) noted that there were no KPIs available for the Portuguese Fire Services at all, although KPIs such as response times and fire safety figures (e.g. the number of 
casualties) might be useful in any context. Further, within the UK financial issues were more emphasized in England than in Scotland, suggesting area and organization specific differences in modus operandi, or what we might call institutional logic.

Differences in the institutional logics thus suggest differences in KPI selection and in KPI use. The UK and Nordic experiences point towards more emphasis on financial logic than in Southern Europe. In the case section we will compare Finland and Spain. We consider understanding the interrelations between the institutional logics and KPIs as a potential avenue for increasing understanding of KPI selection and use in different organizations, which may facilitate projects for change and organizational developments.

\section{Research methods}

KPIs may be selected and used differently in the Finnish and Spanish case organizations because of differences in conditions such as economic pressures and because institutional logics are socially constructed and usually local (see e.g. Lounsbury, 2008; Meyer, 1996). Ontologically and epistemologically this means that case specific analyses and comparisons are helpful in understanding the nature and relations of the co-existing pressures, logics and KPIs in police organizations.

Accordingly, contributions to discussions about institutional logics and KPI design are pursued in this paper in a comparative case setting. European co-operation may increase comparability and coercive institutional pressures based on EU legislation. However, analysis of earlier literature revealed a potential cultural North-South division in the PM of European countries (e.g. Carvalho et al., 2006). Thus the differences among prominent institutional logics may be accentuated by comparing and analysing police work in two very different European countries: Finland and Spain. The comparative case setting facilitates the assessment of similarities and differences in the institutional logics and in KPI selection and KPI use in police work.

The empirical part of our long-term case research included obtaining pre-knowledge by discussions and project work and analysing the differences of the disclosed KPIs, archival data and reports available on the internet. Further, our analysis of the institutional logics is based on understanding the behaviour of organizational actors, which was gained by observations during the pilot project, and through discussions, emails, phone calls and qualitative analysis of follow-up interviews about KPI use and police work. The pre-knowledge of the context was first acquired with a Spanish KPI development project in 2006-2009 and then the research continued as a comparative international case study using both quantitative and qualitative data. The main qualitative data was gathered with eleven (11) recorded semi-structured follow-up interviews of police officers in Spain and Finland in 2012 (see Appendix). The project observations, interviews and other data (notes, emails, PM documents and annual reports) give a longitudinal view of the police work in Finland and in Spain.

In order to understand the relationship between the institutional logics and KPI selection and use we wanted to find differing police organizations where the differences might be 
highlighted and readily observable. Yin (1984) noted that comparison pairs and the use of both numerical and qualitative data may be useful in case studies. We soon noted that there were differences in the KPIs and in the institutional logics of police work and that the differences in KPI selection and use were not fully explained by the differences in the operating circumstances.

Despite the use of several types of data (mixed data) we have mainly followed the traditions of qualitative, descriptive and interpretive case research (Chua, 1986; Vaivio and Sirén, 2010). We use institutional theory, with concepts such as institutional pressures and institutional logics, to better understand how practices are produced and reproduced (Chua, 1986; Modell, 2009; Vaivio and Sirén, 2010). In qualitative research, the social reality (also the meaning of KPIs) is subjectively created and objectified though the interaction of organizational actors (Chua, 1986; Hines, 1988). Qualitative case research involves fieldwork where researchers often gather information directly from the interviewees in an exploratory and inductive manner (e.g. Torres et al. 2011). In qualitative research, the researchers try to build convincing explanations through the interpretation of details and categories in the data, though this involves subjectivity (e.g. Golden-Biddle and Locke, 1993). In order to reduce the amount of subjectivity we used multiple sources of data to support our analysis (e.g. categorizations of KPIs and institutional logics). Differences in PM practices and KPIs may reveal the differences in the underlying institutional logics of police work. Improved understanding of police institutional logics may facilitate organizational analyses and developments.

\section{Spanish Police Case}

\subsection{Background and organization}

The Spanish Police is divided into three bodies: National Police, Civil Guard and Local Police (Law 27/1986 on Police Forces and Security Services). The aims of the Spanish Police are to defend the security of citizens, to maintain order and compliance with the law, and to control traffic. The police work focus areas are: Citizen Security and Harmony, Traffic, and Judicial and Administrative issues (including human resources). In recent years the Spanish Police has gone through organizational and cultural changes and is also focused on disclosing transparent and user-friendly information to the citizens. The Spanish Police must defend the security of about 46.7 million inhabitants including $10 \%$ of whom are immigrants (INE, 2013), and about 60.6 million tourists yearly.

\subsection{Objectives and KPIs of the Spanish police.}

The Spanish Police has traditionally had budgeting and accounting systems but few common KPIs. In the wake of global NPM developments, a central objective also in the Spanish public sector change was to make comparative performance measurements among the local entities and to publish the PM information. Therefore the Spanish Federation of Municipalities and Provinces (SFMP) decided to define a common 
Performance Measurement System for the local authorities of Spain (including town councils, provincial councils, and the island authorities; 8,114 Spanish municipalities in total). Being aware of the challenges requiring local authorities to be more efficient, the SFMP promoted a series of initiatives, among which was the pilot project 'Costs and Indicators for Comparability in Spain' starting with 11 town councils and several universities in 2006-20092. The project had two complementary and sequential goals: to design a costing system for each council based on the traceability of public service activities, and to produce a series of key performance indicators (KPIs) that will provide comparable results and act as a basis for better decision-making from an economic and social point of view. Both the design of the cost allocation system and the definition of KPIs were made in collaboration with the universities and councils.

When the pilot project began, the problematic issues were how to design and formulate the KPIs and who would develop them. They were designed and selected by both universities and councils to make a common framework and a tool for management. However, a conflict between institutional pressures at once became apparent: the municipality managers adapted PM to their needs and political agendas so PM never followed a common target or framework, such as the BSC scheme, even though these were considered legitimate starting-points of KPI planning by university researchers. For example in some municipalities the KPIs were intended for cost comparisons but not in other municipalities. The university participants wanted to design dynamic and flexible KPIs, giving priority to cost-effectiveness and the usefulness of KPIs for police work planning and decision-making, mainly following normative pressures in developing public PM. The top police managers suggested KPIs according to the areas where police work is organized. Police officers at the local level, however, focused on result indicators within the 'managing for outcomes' framework such as the citizens' perception of security. Local police officers also focused on KPIs relating to activities and human resources in the analysis of the Local Police (where police absenteeism was a central concern). Cost and budget KPIs were considered as complementary. In short, there were several actors with different goals and different institutional logics involved in police work KPI development, and over the years much work was done by the university members and the police managers in order to harmonize concepts and achieve a compromise between goals (see also Oliver, 1991). Gradually a consensus was reached and certain KPIs were accepted as suitable measures.

In Table 1 we present some of the most agreed and representative KPIs from each focus area of the Spanish police as well as human resources indicators which were acceptable for each area. Because the populations in Finland and Spain differ, the figures are presented with reference to the population (e.g. per 100 people).

2 For example the city of Madrid was the biggest project participant, see: http://www.femp.es/Portal/Front/ContenidoDetalle/_N1w1oXtNSY0yhZhONawjegNOR9ZAAkyj-XeDdOaxcQ. 
Table 1: SFMP sample Police Indicators.

\begin{tabular}{|l|r|r|r|}
\hline Spanish SFMP police statistics (sample councils) & \multicolumn{1}{|c|}{2007} & \multicolumn{1}{|c|}{2008} & \multicolumn{1}{|c|}{$\mathbf{2 0 0 9}$} \\
\hline \multicolumn{1}{|c|}{ Traffic area } & & & \\
\hline 1. Average traffic accidents with victims per 100 people & 0.32 & 0.29 & 0.28 \\
\hline 2. Average traffic offences per 100 people & 0.17 & 0.17 & 0.16 \\
\hline 3. Average breathalyzer coverage per 100 people & 2.95 & 3.1 & 3.6 \\
\hline 4. Alcohol offences per 100 people & 1.5 & 1.4 & 1.6 \\
\hline Citizen security area & 8.28 & 8.46 & 7.74 \\
\hline 5. Crimes against property per 100 people & & & \\
\hline Judiciary police area & n.a & 0.0284 & 0.0271 \\
\hline 7. Judiciary reports attended per 100 people & 116.16 & 116.55 & 119.45 \\
\hline 8.Total SFMP project funding (€ per 100 people) & & \\
\hline Human resources & n.a & $88.89 \%$ & $93.24 \%$ \\
\hline $\begin{array}{l}\text { 9. Percentage of police effective presence in the street per police } \\
\text { officer per year }\end{array}$ & n.a & 219.00 & 219.00 \\
\hline 10. Number of police officers per 1,000 inhabitants & n.a & $6.96 \%$ & $5.21 \%$ \\
\hline $\begin{array}{l}\text { 11. Percentage of extraordinary hours (overtime) worked per } \\
\text { police officer per year }\end{array}$ & n.a & $7.62 \%$ & $7.58 \%$ \\
\hline 12. Percentage of hours dedicated to training per police officer & n.a & $25.33 \%$ & $20.63 \%$ \\
\hline 13. Percentage of absent hours due to accidents per police officer & n.a & $13.19 \%$ & $15.58 \%$ \\
\hline 14. Percentage of administrative personnel per police officer & & \\
\hline
\end{tabular}

The KPIs in Table 1 are mostly operational service level or output measures which do not necessarily portray the effectiveness of the police very well. It can be stated that absenteeism due to accidents decreased by about 5 percentage points and the extra hours (overtime hours) served by the police decreased about 1.7 percentage points, a reduction which can be a sign of improved police work planning. Additionally the effective presence of police on the street increased by 5 percentage points from 2008 to 2009, and that might be linked to the decrease in the number of total traffic and crime offences, indicating some success in the risk-preventive police work. The number of police officers per 1000 people was 219 in both 2008 and 2009. The number of administrative workers increased about 2.4 percentage points from 2008 to 2009 . More generally, about $71 \%$ of all police costs were personnel costs. Approximately $35 \%$ of costs were incurred by security surveillance operations, $10 \%$ by emergency calls, $25 \%$ by judiciary reports, 25 $\%$ by traffic operations and $7 \%$ by other assignments. Some of the KPIs are difficult to define or measure exactly, for example the 'effective presence'.

When defining activity indicators to measure efficiency and effectiveness, both the police officers and municipality managers wanted to know response times in answering calls. In particular they wanted to distinguish between A-type (most urgent) emergency calls, and non A-type calls. Next, managers required two kinds of outcome indicators: response times and answer percentages. The average response times, i.e. the times it takes for police to answer a call and to go to the location of the emergency, are presented in Table 
2. Interestingly all calls responded to were considered both answered and solved. However, the idea that all calls would be (fully) solved seems unrealistic.

Table 2: Average SFMP sample response time to A-type emergencies

\begin{tabular}{|l|l|l|}
\hline \multicolumn{1}{|c|}{ Time to answer emergencies (in minutes) } & 2008 & 2009 \\
\hline A-type & 13 & 9 \\
\hline Non A-type & 25 & 21 \\
\hline
\end{tabular}

In addition to the traditional indicator areas, coordination was an important area for local managers. This suggests that practical police operations demand co-operation even though the success of co-operation is difficult to measure. In the project there were follow-up meetings every year in order to review the indicator framework and to improve the information in it. If some indicators are considered too delicate for disclosure, too difficult to measure or not relevant to current problems faced by the police, these indicators can be removed and new ones can be added, at least if there is a consensus among the 11 municipalities. However, the follow-ups and KPI changes seemed to require a lot of administrative work and political negotiations. Some of the information is considered confidential so some municipalities do not want to appear under their own names in all reports. This decreases the usefulness and comparability of the data for citizens. Benchmarking based on the disclosed KPIs, however, may facilitate improved comparability as well as improved knowledge of the municipality processes, costs and public service quality. Further, in some local entities there was resistance to co-operation because of different political strategies and because of the downturn in the economic situation which diminished involvement in development projects. Thus understanding the political and economic pressures seemed important in developing local police KPIs (see e.g. Northcott and Llewellyn, 2003).

Based on the project work observations, there were several conflicting institutional logics: KPI selection was affected not only by financial (or NPM style cost-effectiveness pressures) but also by local political negotiations and decisions. These pressures may force co-operation or on the other hand have the effect of isolating some municipalities even more. In some project municipalities the researchers observed a culture change towards openness and learning from others as municipality managers involved in the project lost their fear of disclosing and comparing information with each other (the legitimacy threat being considered smaller than the benefits). As they talked with others they could see the strengths and weaknesses of their operations compared with similar organizations. Some municipality managers are already taking advantage of this experience in order to improve their efficiency and decision-making. For example the managers in the local police in Madrid have begun to design best practices based on the performance indicator design and comparison efforts. Over the years the data have been published and many managers, though not all, have used the indicators. These Spanish experiences suggest a link between institutional logics and KPIs: KPI indicator selection is a social process with several interest groups and, despite some similarities, this process may include local emphases. 


\subsection{Institutional logics in Spanish police work}

In this section we present the qualitative case findings from 5 follow-up interviews in the Central Spain Police District (see Appendix). Generally the interviewees emphasized the operational logic over financial logics or administrative logics. This suggests that the police should focus on crime fighting instead of thinking about the expenses or jurisdiction boundaries. Focus on operational activities is also seen as the traditional focus of the Spanish Police. In the last years, however, with the economic crisis, cost savings are expected especially in administrative areas of police work. The savings may also affect the resources and the duties of local police officers. However, several emphases may be found for example within the operational institutional logic.

When interviewing the Police Chief Manager, an emphasis within the operational focus appeared that highlighted effectiveness, which was perceived as the impact of all police actions on the citizens' perception of security. In this effectiveness oriented operational logic achieving results means a positive social impact, measured by the citizens' perception of security. It is not clear, however, how this perception is measured in detail and if it was measured after the initial pilot project questionnaire to citizens. Thus the KPIs in regular use emphasized the service level outputs, such as working hours. Nevertheless the citizens' perception of security may serve as a general goal of police work and direct attention to services that are expected to affect perceived security.

On the other hand, the police officer (Interviewee 3) believed, despite the expected savings, that the traditional operational logic was still the predominant institutional logic. His view was focused on services, especially on the number of interventions made.

The main objective of the police is to act and our work is measured by the number of interventions made against crimes to people and property even if it is not reflected in result indicators... (Interviewee 3).

The focus on the number of interventions suggests an emphasis on service level outputs within the operational logic of police work. Thus operational logic seems to include two different emphases relating either to effectiveness or to service level outputs. However, the different emphases found may enforce each other: within the operational logic a specific focus on the service level (by increasing the hours of police work carried out in the street) may facilitate effectiveness, improve, for example, the citizens' perception of security.

Further, the Chief Manager considered that in order to change an operational logic a strong administrative emphasis is necessary so as to create control over performance and bonus payments according to the police department strategy. This suggests that the institutional logics presented in the literature may work in combination, especially in change situations.

In fact, in order for our police workers to interiorize the new model, we are trying to link the institutional logics with results and to achieve a variable salary [bonus]...this is considered a future development area in the short term. ... The Police need to be on the street ... Citizens' perception of security is the main focus. (Interviewee 1) 
The police officer, instead, doubted the accuracy of the link between results and variable bonuses because prioritization of KPIs is difficult. However all interviewees agreed that police work has focused on civil security and harmony issues and KPIs, particularly during the last few years.

All police areas focus on achieving an improvement in civil security and harmony, where indicators such as 'drug offences in schools' or 'alcohol offences' or 'traffic accidents with victims'... are more important currently because of their social impact on citizens' perceptions of quality in police services (Interviewee 2).

When asked about the main threats to good quality police work, interviewees answered that police absenteeism was the principal threat on operational quality, even over the budget decreases, because diminishing absenteeism might reduce the expensive overtime hours needed. Therefore a human resources PM area was added, with indicators of absenteeism and extra hours (see Table 1). Thus reducing absenteeism is a common target that may align the different institutional logics (see Rautiainen and Järvenpää, 2012; Reay and Hinings, 2009).

Our main concern is motivation in our police workers in order to improve the results towards the social impact in the citizens' perception of good quality in the police service... though... we are facing a continuous reduction in the budget. (Interviewee 1).

The last legislative labour reform of the Spanish Government has contributed towards reducing the absenteeism figures. (Interviewee 4)

The traditional operational police work logic was dominant in some answers, where it was visible in things being done like before, with little emphasis on financial constraints.

In central Spain there are so many concerts, football matches and demonstrations against Government measures that the police cannot forecast the budget accurately, since the cost of the number of police workers needed during weekends for extra hours of service constantly exceeds the budget...This is where the objective of citizen security is prioritized over financial constraints (Interviewee 2).

The police force is a very traditional service where changes are made slowly and smoothly, including the changes in the Balanced Scorecard. (Interviewee 5)

The police officers affirmed that cost indicators were not relevant when having to make interventions. This suggests separating some operational and financial decisions in order to cope with multiple logics (see Reay and Hinings, 2009). However, in situations of potentially increased conflict among the institutional logics, careful budget planning might allow for reactive operations without jeopardizing the financial targets.

When the police have to act against crime, traffic or offences against the security of citizens, they will not look at the cost of the activity, but, currently, reductions in the budget are made by reducing investments drastically, so we have no more new vehicles, offices etc. (Interviewee 3).

When asked about the financial issues the police general manager and the administrative officer answered that cost indicators have about the same relevance as in the previous 
years, even though savings and budget reductions have been made. However, because of the unanticipated demonstrations against the Government, the need for police extra hours has remained high, with the effect of intensifying savings pressures on the Police. This threatens for example the quality of equipment.

We are very worried about the cost in terms of personnel deployed for each activity of the Police: traffic offences, alcohol offences, crimes against property and judiciary reports completed (Interviewee 2).

The police financial team is currently trying to ensure that police workers have the best possible resources, uniforms, cars and guns with the minimum economic resources... (Interviewee 4)

Thus the administrative officers emphasize also the classic NPM style measures such as unit costs in the Spanish Police. Further, increased control over spending was noted, a point which in our view suggests increased importance of the administrative logic which may cause a threat to operational flexibility and efficiency:

From the administrative point of view the increase in rules and controls is the major threat. For example when the forensic police urgently require different physical resources, they need to fill in a high number of applications and reports... (Interviewee 5)

\subsection{Ways of coping with different logics}

The Chief Manager had a strong focus on operational effectiveness focus (in terms of the citizens' perception of security. The financial and administrative issues needed managerial attention too but they were perceived as supporting the main operational goal, the citizens' perception of security.

There is a shift in the strategy, it is clearer and it is as if we are building a pyramid ... where ... the operational outcomes are at the top of the pyramid supported by administrative and financial issues situated at the bottom off the pyramid. (Interviewee 1)

Further, the general aim of reducing absenteeism was considered a very important goal because reducing absenteeism may improve efficiency and reduce costs, such as overtime payments and the cost per hour of police being present thereby aligning the conflicting logics (or goals such as savings and high operational quality). With respect to the usefulness of the KPIs defined, the interviewees answered that their experience was positive, even if a reduction of the number of performance measures has been made. This change in KPI use may indicate increased focus in decision-making as well as changes in strategy or in the operating conditions.

Over the last few years, since the implementation of the Balanced Scorecard, indicators have been reduced in number and adapted to the objectives defined in the police strategy... (Interviewee 1)

Crimes are changing, with international terrorism or new types of crimes on the internet, so new units are created to restrain these crimes, with the result that new indicators are defined to measure this new police work as others are eliminated. (Interviewee 4) 
The Spanish case evidence pointed out that the process of selecting KPIs is social and even political, and that service level (in terms of working hours and presence in the street) and effectiveness (in terms of high security perception) are the main goals or priorities within the operational logic of the Spanish police. This suggests several possible emphases regarding the institutionalized priorities of police work. For example, focus on presence (hours in the street) or on solving percentages might lead to different decisions in work planning. On the other hand, a threat to traditional police work is posed by bureaucratic activities which keep officers invisible in offices, instead of being on the streets contributing to the citizens' perception of security. Furthermore the financial crisis is increasing the prioritization of financial and material resources, and that requires coping with conflicting institutional logics.

\section{Finnish Police Case}

\subsection{Background and organization}

In Finland there are 5.35 million inhabitants, and far fewer immigrants than in Spain. However, about 6 million tourists visited Finland in 2013 (Visitfinland, 2014), so the number of tourists in Spain and Finland is reasonably comparable relative to their respective populations. The Finnish Police is organized as a national unit under the Ministry of Internal Affairs. During the data collection period of this research there was the Central Police Government and 24 local police departments (with many local police stations or offices), but since the beginning of 2014, because of cost cutting, there are now 11 local police departments in Finland. The local police departments are not organized under local government organizations, but they all belong to the same national Finnish Police. This may diminish co-operation problems among police departments and increase PM coherence. Additionally there are three national police units: The National Bureau of Investigation for international and financial crimes, the Police College of Finland and the Finnish Security Intelligence Service for national security.

\subsection{Objectives and KPIs of the Finnish Police}

Finnish police performance statistics are systematically gathered in the Crime Reporting System by the local police departments. The separate Emergency Response Centre (where citizens call for emergency help) keeps statistics about the response times and the number of emergency calls. The Finnish Police also has budgeting and accounting systems as well as BSC type collections of KPIs. Lately attention has been paid to the accuracy of statistics, because statistics on costs and effects are an essential part of funding negotiations with the Ministry of Internal Affairs. With the reduction in resources, the response times have been prioritized; for example crime investigation times do not always need to be fast, but response times for urgent calls do need to be. The statistics can be obtained through a Police Management Portal and additionally the Police College of Finland keeps statistics at the national level. The most important performance information (such as an average regional response time) is openly given to the media and 
publicly disclosed on the internet, mostly at the national (aggregate) level. (Source: telephone interviews of two Finnish police officers on 31.5.2011.)3

The Finnish police KPIs have been developed over time in several development projects within the Finnish Police. There were fewer interest groups involved in developing the KPIs in Finland than in Spain. However, the Finnish Ministry of Internal Affairs has been putting high financial and cost-effectiveness pressures on the local police. The KPIs in Table 3 include solving percentages as a category measuring the effectiveness of crime investigation. Similar KPIs are followed both at the top and local level, though traffic offences are categorized in more detail even at municipal level. In order to compare Finnish and Spanish statistics, we disclose below the 'per 100 people' figures as in Table 2. Total funding is calculated 'per capita'.

Table 3: Finnish Police work indicators (The Annual Book of the Finnish Police, 2009)

\begin{tabular}{|l|c|c|c|}
\hline Finnish crime statistics & $\underline{2007}$ & $\underline{2008}$ & $\underline{2009}$ \\
\hline Surveillance of traffic and security & & & \\
\hline 1. Number of crimes against property/ 100 people & 4.73 & 4.83 & 4.76 \\
\hline 2. Drug offences/ 100 people & 0.31 & 0.31 & 0.34 \\
\hline 3. Severe crimes against the person/ 100 people & 0.07 & 0.07 & 0.06 \\
\hline 4. Financial fraud and other crimes/ 100 people & 0.03 & 0.03 & 0.04 \\
\hline 5. Traffic offences/ 100 people & 3.88 & 3.45 & 3.20 \\
\hline 6. Other crimes/ 100 people & 6.31 & 7.79 & 8.79 \\
\hline 7. Total number of crimes reported/ 100 people & 15.32 & 16.48 & 17.19 \\
\hline Crime Investigation & & & \\
\hline 8. Solving \% of crimes against property & $38.5 \%$ & $37.8 \%$ & $38.9 \%$ \\
\hline 9. Solving \% of severe crimes against person & $76.8 \%$ & $83.5 \%$ & $85.7 \%$ \\
\hline 10. Solving \% of other crimes & $67.6 \%$ & $65.9 \%$ & $65.8 \%$ \\
\hline 11. Average solving \% (average of lines 8 to 10) & $60.97 \%$ & $62.40 \%$ & $63.47 \%$ \\
\hline 12. Ratio of juvenile criminals (\% of all criminals) & $15.46 \%$ & $14.50 \%$ & $13.28 \%$ \\
\hline 13. Total funding of Finnish police/people & $124.06 €$ & $133.46 €$ & $142.06 €$ \\
\hline Licence services & & & \\
\hline 14. Total No. of Licences and permits given & 986352 & 1096010 & 1086798 \\
\hline Administration & & & \\
\hline 15. Total police officers in duty & 7579 & 7546 & 7778 \\
\hline 16. Total police officers per 1000 people & 1.42 & 1.42 & 1.45 \\
\hline 17. \% administrative people out of total police & $13.27 \%$ & $14.34 \%$ & $14.01 \%$ \\
\hline
\end{tabular}

In Table 3 the crime investigation KPIs depict mostly the quality or success of police work. The percentage of crimes against property that were solved was about $38 \%$ and the actual number of those crimes has not varied much during 2007-2009. Because at the same time more overall funding was needed, it might seem that cost-efficiency has decreased. However, if one takes into account the increase in the percentage of severe crimes being solved and the potential risks associated with the increased number of drug offences, the picture changes. Further, more white-collar crimes (financial fraud and

3 In Finland there was no common KPI pilot project with the police and the researchers. Telephone discussions, emails and reports were used to gain an understanding of police work and KPI developments. 
other crimes) were investigated in 2009. The diminished number of traffic offences may be due to diminished patrol surveillance and the trend towards automatic traffic control cameras, though it may also indicate assigning resources to other - more strategic - crime fighting duties. The decreasing number of suspected juvenile criminals is considered a good indicator of success in police preventive work, but any indicator is hardly an absolute sign of success in police crime prevention.

Like in Spain, we see both service level output KPIs and effectiveness KPIs in Table 3. Effectiveness, however, is measured as solving percentages (easily measurable KPIs instead of citizens' perception of security). There are relatively few cost based KPIs in the Finnish reports. The total number of police officers (of which $13 \%$ are women) was increased by $3 \%$ to 7778 in 2009 and thus the number of police officers per 1000 people was 1.45 . The proportion of administrative workers was $13.27 \%$ in 2007 and $14.01 \%$ in 2009. More generally, about $75 \%$ of all police costs were personnel costs; about $9 \%$ were purchases of services, $8 \%$ were rental costs and $4 \%$ were material costs. Functionally about $30 \%$ of costs were incurred by surveillance operations, $10 \%$ by emergency calls, and $45 \%$ by crime investigation.

Table 4: Average response times in minutes for A-type emergency calls in Finland

\begin{tabular}{|l|c|c|c|}
\hline Response time (in minutes) & $\underline{2007}$ & $\underline{2008}$ & $\underline{2009}$ \\
\hline 1. Helsinki & 11.5 & 11.6 & 8.4 \\
\hline 2. Southern Finland & 11.5 & 11.1 & 11.1 \\
\hline 3. Western Finland & 13.2 & 12.0 & 12.9 \\
\hline 4. Eastern Finland & 14.4 & 14.3 & 16.0 \\
\hline 5. Oulu Region & 13.7 & 11.9 & 12.6 \\
\hline 6. Lapland & 18.1 & 17.7 & 17.7 \\
\hline AVERAGE (minutes) & 13.73 & 13.10 & 13.12 \\
\hline
\end{tabular}

The average response times for important emergency calls in Finland in 2009 varied from about 8.4 minutes in Helsinki to about 18 minutes in Lapland (see Table 4). Table 4 shows that on average the response times have decreased. The average effectiveness may have increased but the regional differences in the level of service have grown. This suggests that the economic pressures have been coped with by prioritizing densely populated areas.

The qualitative data in the Annual Book of the Finnish Police 2009 was also analysed. The Chief of Police noted that the organizational structure had been changed by combining small units. The annual target and funding negotiations between the police and the Ministry of Internal Affairs were emphasized. These yearly agreements guide the operations but are subject to political negotiations. Further, the Chief of Police called for more cost-effective work processes and co-operation with other official bodies (e.g. Customs). In addition, a citizen safety index was disclosed, which is based on crimes per citizen, but in such a way that severe crimes are given more weight. However the exact ways of calculating this effectiveness figure were not disclosed. 


\subsection{Institutional logics in Finnish police work}

In this section we present the qualitative data gathered from the 6 recorded follow-up interviews in Finland (see Appendix). In the Central Finland Police Department (CFPD), four interviews were conducted and the prominence of financial logic in managerial decision-making soon became evident. The importance of the financial focus noted in the four CFPD interviews was confirmed by two comparative interviews in the Eastern Finland Police Department.

It was noted that success in police work is difficult to define, and that under the current emphasis on financial issues some minor offences cannot be investigated. The media and citizens' interests may also have some effect on what is selected for further investigation.

A simple overall measurement is hard to find. For example through-put time is not necessarily the measure of success in passport issues, while on the other hand the number of passports is easy to count ... But which weighs more: 1 financial crime or 50 thefts. ... The investigation of a financial crime case may take two years. ... The severity of crimes is not clear ... [Interviewee 1].

This excerpt, however, suggests that severity of crimes might serve as a basis for prioritization. In accounting terms this might be 'materiality' which is especially visible in financial crime investigations with the term 'financial interest involved'. However, some police officers did not fully agree on the prioritizing of police work.

We measure the financial interest involved in the (financial) crime ... such as in a tax fraud there is the amount of taxes evaded. [Interviewee 2]

The quality of inspection [e.g. time spent] has to be at rational limits ... What is easy to measure gets measured, response times or the number of crime reports. One can educate or give fines but what is the final effect? ... Not everything can be investigated. But media interests or social status should not matter... Ideally, we should investigate everything, though for example severe crimes often touch several people. In my view the Police should not prioritize ... law makers [politicians] should decide what should be focused on ... a good service can’t be had cheaply. [Interviewee 4].

Further, even concepts that may seem relatively simple, such as the solving percentage, are not always clear.

... if we send the case to the prosecutor it is considered solved: we have a suspect, but who is not necessarily guilty in court. It may take 10 years to get the final verdict [Interviewee 2].

After the organizational changes in 2009, the amount of bureaucracy increased. However, the administrative support processes do not necessarily contradict operational targets, but clear rules are needed because of the increased complexity of operations (e.g. bigger units). Without clear rules the employees cannot know what is expected from them, a situation which may lead to lack of focus. Further, there is the risk of inequality and costly errors if rules for purchases etc. are missing.

Now [after a fusion of 5 small police units into CFPD in 2009], when the size of the organization is about 400 persons, there are longer distances and 7 offices, so inevitably the share of formal bureaucracy or administration has increased in order to have foreseeable 
operations, so that the personnel know what is expected from them and they know what to expect from their police district. Making arrangements with everyone individually does not work anymore in this world ... the significance of administrative or formal guidance has increased. Some feel it is frustrating but on the other hand it is necessary. [Interviewee 3]

The latest administrative projects concerning the organizational structure came into effect in 2014 (e.g. combining police departments) but reorganization is done so as not to impair the quality of operational police work much, and the savings are mostly pursued by cutting administrative staff and overtime pay. This suggests that cutting bureaucracy suits both operational and financial decision-making logics.

There will be cuts in administrative personnel. Also the real estate needs are reconsidered. By reducing the management and administration we make these savings ... this is a reform of the organization and quite financially based ... but we have set goals so that the operational results and operational efficiency are maintained as much as possible. ... If the unit size grows, this is not traditional local police work anymore. Economies of scale may be obtained from administrative work. [Interviewee 1]

The savings with new bigger organizations allow more police forces to focus on acute problems, but closure of small police stations may leave distant rural areas with less emphasis, by diminishing the traditional local police surveillance work.

The interviewees noted a shift in the emphasis of police work logics: during recent years financial logic has somewhat superseded operational logic in importance. Financial emphasis is now more visible in most organizational activities: in the budgeting process, in work hour planning and in organizational changes - both at the local and at the national police levels. In current work planning the financial issues are considered first and only then the operational needs:

Traditionally, if I consider the local police, the objective has been to fit together the operations and financials but now let's say during the last three years ... it has been ... turned around ... it's about fitting together the financials and the operations. That is to say, more and more it is the financial accountability that defines the limits of the operations. [Interviewee 3]

Financial logic has been focused on also in the budget negotiations where the local police departments negotiate over targets and funding with the central police unit (called Police Government). The average response time is the most closely followed operational KPI in the budget negotiations, and consequently the focus on average response time has increased also at the local level.

In our local police result agreement with the Police Government, we agree on both financial and operational goals.... At the national level the financial targets count, while locally we get certain resources, money and man-years, and then manage operational issues and response times. ... The most important operational measure ... is the average response time... it is in our result agreement and we also follow it closely by areas. It is central, it measures the service level. Additionally we have investigation time and solving percentages ... but no allround, clear, cost-effectiveness measure is available [Interviewee 1] 
Thus response time is considered as a proxy measure for the operational service level while financial aspects are more considered in organizational design and in work planning.

... Current crimes, even global crimes, require sizeable units in order to respond effectively... but the organizational changes [in 2009 and 2014] are not based on crime considerations but on financial aspects. [Interviewee 1]

\subsection{The ways of coping with different logics}

Despite the focus on financials and good budgetary discipline, by prioritizing their operations (e.g. having police officers present at known problem times, such as Friday nights, but not much on Sundays) the CFPD managed both to reduce costs and to improve their average response time KPI. As a response to the economic and normative pressures surrounding police work, the focus on average response time may resemble compliance, compromise but also manipulation (see Oliver, 1991; Rautiainen and Järvenpää, 2012). With emphasis on a certain KPI (the average response time) and with careful work planning the potential conflict between operational logic and financial logic was reduced.

The common modes of operating, through meetings and discussions and trainings, start to have an effect ...We have improved our operational results and at the same time we have made a significant improvement in costs: these are not conflicting ... We made a whole new tool for planning, an Excel based table, which combines operational planning, personnel management and financial management. ... This has brought a common work vision for us. ... The citizens sometimes complain that we have too few personnel in some locations. But our results show that this kind of optimizing has worked out. ... planning tends to spread out ... the way of thinking changes in general towards more systematic management ... but with hard work. [Interviewee 3]

In particular, the notions 'common modes of operating', 'these are not conflicting', and 'the way of thinking changes' suggest that a new way of coping with multiple institutional logics has been developed, thereby making the use of resources more costeffective. This development might be called as risk-based approach on improving main KPI results (not all KPIs, and the focus is on average KPI results). However, this may also be seen as strategic alignment of logics, where especially the financial and operational logics do not conflict but better perceived cost-effectiveness is achieved by saving money and improving few main operational KPI results. This strategic and riskbased way of coping with the conflicting logics builds on both the idea of costeffectiveness and on local expertise on assessing risks so that resources are used at times and in places where they are needed most. If this way of coping with different logics is considered successful it may gradually be institutionalized into common (strategic or risk-based) logic of decision-making.

We need to shape our operations according to the case density (or crime risk) and focus our operations on places where there is the greatest call pressure. [Interviewee 3] 
The case density means reported crime cases per area (e.g. crimes/square kilometre) and it also serves as the expected crime risk or likelihood of calls, which varies depending on, for example, the day of the week, the area of the city and on big events such as festivals. Further, analysis of last year's work hours and the percentage of the annual budget spent during different periods facilitated more precise estimates of monthly working hours and other resource requirements.

For every three week work term (schedule), we calculate its percentage ... of the annual total budget, so that we have $100 \%$ as the whole year spending ... every work term was planned according to budget constraint. When we have ... a big event, we have enough police officers there, at least as much as possible (in order to still stay within the budget)... It is our informed decision, it's not by accident... if the police are there or not. [Interviewee 3]

We have reduced additional payments for overtime, travelling, training and so on. ... We forecast the work force needs ... within the limits of the finances. [Interviewee 4].

All in all, the Finnish and Spanish case studies point out that for example complex processes with administrative rules and political budget negotiations affect police work decision-making, involving multiple institutional pressures and logics, highlighted by the current financial distress. The different institutional logics allow for different interpretations of KPIs and different interpretations of effectiveness (whether it is measurable in terms of response times etc. or whether it is a more abstract safety perception). This suggests emphasis (or focus) on either savings or cost-effectiveness in the financial logic; emphasis on the service level or effectiveness in the operational logic; and emphasis on either support or suppressing bureaucracy in the administrative and political institutional logic. Further, there may be some reciprocity in changing organizational goals, KPIs and institutional logics. A common goal such as reducing absenteeism or accepting risk-based resource planning may be a successful compromise response to institutional pressures and also a way of coping with the conflicting institutional logics (see Oliver, 1991; Reay and Hinings, 2009). The risk-based allocation of resources may also be seen as an attempt to go beyond classic NPM style unit cost measures in public sector services (towards post-NPM style public management, see Lodge and Gill, 2011).

\section{Discussion}

The case findings are summarized in Table 5, which illustrates the main institutional logics found in the case police organizations, called 'operational logic' in Spain and 'financial/NPM logic' in Finland. Aspects of the typical institutional logics (suggested by earlier literature) were found in the cases, but we noted that the logics may include different emphases. For example the administrative logic may be entangled with political decision-making in the public sector case organizations. This means that, especially in the process of selecting the KPIs, there can be multiple administrative and political decisionmaking interests involved in police work which can either support or oppose operational improvements. Administration was seen by police officers both as a good thing that unifies practices and as a menace causing bureaucracy and reducing operational time in the field. The Financial/NPM logic in decision-making in our cases seemed to involve 
either savings emphasis (e.g. saving money by reducing operative quality) or an emphasis on risk-based cost-effectiveness developments. Operational logic emphasis in police work seemed to mean that police officers in their duties are mostly concerned with service level output issues and KPIs, such as work hours, or more widely with effectiveness issues and KPIs, such as the citizens' perception of security.

Table 5: Institutional logics and main KPIs in Spain and Finland

\begin{tabular}{|l|l|l|}
\hline & Spain & Finland \\
\hline $\begin{array}{l}\text { Characterization of } \\
\text { the institutional } \\
\text { logics: }\end{array}$ & $\begin{array}{l}\text { Operational logic, with both } \\
\text { effectiveness and service level } \\
\text { emphases found. }\end{array}$ & $\begin{array}{l}\text { Financial/NPM, including a } \\
\text { savings emphasis or an emphasis } \\
\text { on risks and cost-effectiveness. }\end{array}$ \\
\hline $\begin{array}{l}\text { Main KPIs } \\
\text { selected: }\end{array}$ & $\begin{array}{l}\text { Citizen perception of safety, } \\
\text { response time, surveillance hours, } \\
\text { Police absenteeism. }\end{array}$ & $\begin{array}{l}\text { Response time, solving \%, budget } \\
\text { and cost measures. }\end{array}$ \\
\hline $\begin{array}{l}\text { How do } \\
\text { institutional logics } \\
\text { affect the use of } \\
\text { KPIs? }\end{array}$ & $\begin{array}{l}\text { Operational logic promoted wider } \\
\text { effectiveness KPIs, such as the } \\
\text { citizen perception of safety. Also } \\
\text { service level KPIs, such as } \\
\text { surveillance hours, were } \\
\text { important. Reducing absenteeism } \\
\text { serves both emphases. }\end{array}$ & $\begin{array}{l}\text { Financial logic promoted budget } \\
\text { and efficiency KPIs and monetary } \\
\text { savings, but improving KPIs } \\
\text { encouraged some risk analyses } \\
\text { and gradually led to a cost- } \\
\text { effectiveness emphasis. }\end{array}$ \\
\hline
\end{tabular}

The differences in the processes of KPI use in Spain and in Finland reflect the differences in the institutional logics. Cost-effectiveness may be pursued with different emphases, however, even within a certain institutional logic. For example, the risk analysis in Finland led to limited work force on Sundays for savings reasons but, because there were also few calls on Sundays in Finland, the average response time was not seriously affected. This suggests that the different institutional logics may be aligned and that even KPI 'manipulation' (e.g. with a focus on average, instead of always similar response time) is not necessarily a problematic response to institutional pressures (as seen by Oliver, 1991), because a well-selected KPI may still promote cost-effectiveness and oppose suboptimal behaviour.

In Table 5, the effectiveness logic emphasis means a focus on the effects on the public, portrayed for example in the citizen perception of safety KPI in Spain. In the servicelevel emphasis, managerial focus is on the capacity to provide services and on such KPIs that portray, for example, the pre-emptive (or visibility related) operational service level, such as surveillance hours. In Finland there were some efficiency or success related KPIs (e.g. the percentage of solved cases) in use, which, accompanied with the savings, indicate the prominence of financial/NPM logic emphasis among the Finnish police officers, particularly at the top management level.

Some case-specific differences may be attributed, however, to differences in the organization of the police. Spain has three police bodies: the National Police, the Civil Guard and the Local Police, an arrangement, which may lead to more administrative negotiations in the KPI selection phase. The Finnish Police is basically the one National 
Police with its local offices, which are independent of municipal politics. A simple organization structure may diminish administrative and co-operation problems.

Further, to summarize the multiple institutional logics found in the case organizations, we next present a detailed categorization, where we note that institutional logics may include subtle but still distinguishable emphases. Further, we note that administrative and political issues cannot always be separated in the public sector. The institutional logic categories found are: 1) financial/NPM logic, which, in our view can include emphasis on either 'savings' or 'cost-effectiveness'; 2) operational logic, with emphasis on either 'service level' (e.g. working hour KPIs) or 'effectiveness' (e.g. the security perception); and, 3) the administrative and political logic, which can include emphases that either 'support' or 'suppress' operative excellence.

Considering the different emphases, for example administrative and political negotiations may support (enable) operations by providing effective human resources planning and resource prioritization. However, administrative and political negotiation practices may also suppress (constrain) operational efforts by imposing excessive bureaucracy (meetings, negotiations etc.), which cloud the strategic focus of the organization (see Batac and Carassus, 2009; Olson et al., 2001; Tessier and Otley, 2012). In Finland, the financial logic sometimes overrides other issues and the focus of KPI use was often on savings. However, a cost-effectiveness emphasis with risk-based work hour planning reduced the negative effects of savings on the operative processes, and was even of strategic help for operations. In Spain, both the service level output KPIs and effectiveness in terms of citizens' perception of security were emphasized by different members of the police personnel. Further, reducing absenteeism served several organizational goals. In Spain, the effect of political negotiations in the KPI selection process seemed stronger than in Finland.

In the cases, ratio type KPIs or response times are basically comparative but there were national differences in the openness of reporting and in the definitions, such as defining 'solving a case', which allow some room for compromises and manipulation. More police officers work on surveillance operations in Spain, whereas in the sparsely populated areas of Finland it is not feasible to finance such activities. In Spain there are more mass events such as football games or concerts which are susceptible to traffic problems and to public unrest. In Finland these events may attract 5000 spectators, whereas in Spain there may be 75000 spectators present. Further, there is more tourism and immigration in Spain, which require more police presence. These differences make KPIs difficult to compare and manage internationally.

\section{Conclusions}

This paper analysed KPIs and the institutional logics of police services in Finland and in Spain. This selection of case countries reflected the differences found in the earlier literature. We also analysed the ways of coping with conflicting institutional logics in the case countries. Our comparative case study highlighted differences in the institutional 
logics and their effect on the selection and use of KPIs. Generally our findings emphasize the case specific social construction of the meanings of KPIs under multiple institutional logics. Our findings indicate multiple co-existing institutional logics with several possible emphases (or focuses) allowing multifaceted dynamics of conflict and co-operation between the institutional logics in decision-making.

The current financial distress and the consequent pressures to both make savings and be effective were reacted to in different ways. In Spain there was considerable focus on the operational outcomes, while in Finland the prioritization of activities was mostly based on financial considerations. In Spain the political and administrative institutional logics affected the KPI selection more because of the multiple actors involved in goal-setting, though there was a common aim to decrease police absenteeism. The work hour allocation in Finland was based on earlier experience of risks and resource needs, which, surprisingly, allowed both for savings and improving average response times. This indicates that institutional logics have general features but also case specific emphases which, however, need not conflict but may co-operate.

As expected (in line with Carvalho et al., 2006; Reay and Hinings, 2009) we found differences in the importance of the institutional logics between the Spanish and Finnish police. However we also found different locally constructed emphases within the institutional logics. We noted that some of the conflicts among institutional logics could be diminished by emphasizing a common goal or system and by organizational learning of earlier experience. For example cost-effectiveness can be sought by adopting a riskbased planning that emphasizes few 'strategic' goals as a response to resource cuts and operational requirements (see e.g. Batac and Carassus, 2009; Lapsley, 2009; Oliver, 1991; Reay and Hinings, 2009; Urquía and Robleda, 2013).

Using risk analyses, in order to both understand local circumstances and to improve costeffectiveness, may be seen as strategic alignment of logics, which, if considered successful, may gradually emerge as a new logic in operations, for example as a 'beyond NPM logic' aligning the earlier logics (see Lodge and Gill, 2011). From the managerial point of view, developing a common goal may facilitate a selection of a coherent set of KPIs which may eventually help in the alignment of the conflicting institutional logics. This suggests that change in organizational processes and KPIs should not be arbitrary, but rather based on long-term strategic analyses (Collier, 2006). Further, other users of the disclosed information such as citizens and researchers may gradually benefit from better KPI accuracy and comparability and strategic focus.

We contribute to understanding the different emphases of the institutional logics in police work and we clarify how the locally constructed differences in institutional logics affect the processes of KPI selection and KPI use in Finnish and Spanish police. We argue that this co-existence of multiple institutional logics with different (case and time specific) emphases can partly explain the differences and even difficulties noted in KPI selection and use, as well as the slightly varying responses to PM pressures in Finland and in Spain (see also Carmona and Grönlund, 2003; Järvinen, 2006; Navarro et al., 2008; Oliver, 1991; Rautiainen and Järvenpää, 2012). For example, financial logic and financial KPI 
emphasis may seem to constrain operational work with savings but may also result in enabling operational developments since a cost-effectiveness emphasis may have the effect of making more resources available in certain areas or at expected times of high crime risk (cf. Tessier and Otley, 2012).

In Finland the financial/NPM logic of decision-making was often prominent, and it was reflected in the prioritizing of budgets and in the focus on few effectiveness KPIs. In Spain, at the level of police officer work and also at the managerial level, the operational logic was more prominent; although for example the administrative and political logic also had influence in the KPI selection process. The case-specific emphases in the institutional logics can clarify KPI selection and KPI use. For example political aspects can be an essential part of the KPI selection process in the public sector and need to be considered in public sector case analyses. We suggest that selecting and using KPIs according to the currently prominent logic facilitates reinforces the status quo, and may lead to both coupled and decoupled PM rules and routines depending on the effect of other institutional logics. On the other hand, a managerial attempt to select and use KPIs against, or beyond, the current logic may facilitate accounting and organizational change, even changes in the institutional logic.

We also noticed that police PM data was not very comparable because of the differing level of detail and because the percentage of crimes solved, for example, was not comparatively defined - or disclosed, a fact which suggests that there is still work to do in making police PM comparable in Europe (in line with Carvalho et al., 2006). Nevertheless, in both countries the response times to calls was a major quality indicator of police work and in both countries it improved during the research period. Even one successful common goal or KPI can be a starting-point for improving cost-effectiveness successfully in organizations with multiple institutional logics. Detailed operational information may suit local police officers, but more general indicators can be useful for politicians, academics and other decision-makers. The measurement of police work is difficult because it is not clear what the effect of the time spent on particular activities has on the quality of the work. Police PM might benefit from using multiple KPIs, for example financial measures and considerations of citizen safety. Ratio type KPIs or "per capita' figures may be comparable, and proxy indicators of quality may include for example the percentage of crimes solved and average response times.

In line with Malmi and Granlund (2009), some practical ideas may be suggested for future development. The more complex the organizational structure, the more vulnerable it seems to be to administrative and political conflicts over what KPIs to select and what duties belong to which organizational unit. Further, conflicting institutional logics might be aligned with strategic choices and risk analyses. This paper highlights several future lines of research, such as analysing the reasons for not disclosing comparable figures among countries and years, and studying the selection and use of KPIs in police work internationally. Further study is also needed in order to find the causalities between police work input and output measures. Finally, research is encouraged into understanding the change of emphasis within institutional logics. 


\section{REFERENCES}

Adcroft, A. \& Willis, R. (2005). The (un)intended outcome of public sector performance measurement. The International Journal of Public Sector Management, 18 (5), 386-400.

Ammons, D.N., Coe, C. \& Lombardo, M. (2001). Performance-comparison projects in local government: Participants' perspectives. Public Administration Review, 61 (1), 100-110.

Ammons, D. \& Rivenbark, W. (2008). Factors influencing the use of performance data to improve municipal services: evidence from the North Carolina benchmarking project. Public Administration Review, 68 (2), 304-318.

Annual Book of the Finnish Police 2009. [Poliisi. Vuosikertomus 2009]. (http://www.poliisi.fi/poliisi/home.nsf/ExternalFiles/Poliisin_vk_2009_p/\$file/Poliisin_vk_ 2009 p.pdf )

Arnaboldi, M. \& Lapsley, I. (2004). Modern costing innovations and legitimation: a health care study. Abacus, 40 (1), 1-20.

Batac, J. \& Carassus, D. (2009). Interactions between control and organizational learning in the case of a municipality: A comparative study with Kloot (1997). Management Accounting Research, 20 (2), 102-116.

Boland, T. \& Fowler, A. (2000). A systems perspective of performance management in public sector organisations. International Journal of Public Sector Management, 13 (5), 417-446.

Bourdieu, P. (1990). Logic of Practice. Translated by Nice, R., Stanford University Press, California.

Bowerman, M. (1995). Auditing Performance Indicators: The Role of the Audit Commission in the Citizen's Charter Initiative. Financial Accountability and Management, 11 (2), 171183.

Bowerman, M., Francis, G., Ball, A. \& Fry, J. (2002). The evolution of benchmarking in UK local authorities. Benchmarking: an International Journal, 9 (5), 429-449.

Boyne, G.A. (2003). What is public service improvement?. Public Administration, 81 (2), 211227.

Boyne, G.A., James, O., John, P. \& Petrovsky, N. (2010). Does Political Change Affect Senior Management Turnover? An Empirical Analysis of Top-Tier Local Authorities in England. Public Administration, 88 (1), 136-153.

Brignall, S. (1993). Performance measurement and change in local government: a general case and a childcare application. Public Money \& Management, 13 (4), 23-30.

Burns, J. \& Scapens, R.W. (2000). Conceptualizing management accounting change: an institutional framework. Management Accounting Research, 11 (1), 3-25.

Burns, J. \& Vaivio, J. (2001). Management accounting change. Management Accounting Research, 12 (4), 389-402.

Caiden, G.E. (2006). Improving Government Performance. Public Administration Review, 66 (1), $139-142$.

Carmona, S. \& Grönlund, A. (2003). Measures vs. Actions: the balanced scorecard in Swedish Law Enforcement. International Journal of Operations \& Production Management, 23 (12), 1475-1496.

Carvalho, J., Fernandes, M., Lambert, V. \& Lapsley I. (2006). Measuring fire service performance: a comparative study. International Journal of Public Sector Management, 19 (2), 165-179.

Chua, W.F. (1986). Radical developments in accounting thought. The Accounting Review, 61 (4), 601-632.

Collier, P.M. (2006). In Search of Purpose and Priorities: Police Performance Indicators in England and Wales. Public Money \& Management, 26 (3), 165-172.

Dalehite, E. (2008). Determinants of Performance Measurement: An Investigation into the Decision to Conduct Citizen Surveys. Public Administration Review, 68 (5), 891-907. 
Diez, A. \& Mancebon, M. (2002). The efficiency of the Spanish police service: an application of the multiactivity DEA model. Applied Economics, 34 (3), 351-362.

DiMaggio, P. \& Powell, W. (1983). The iron cage revisited: institutional isomorphism and collective rationality in organizational fields. American Sociological Review, 48 (2), 147160.

Dorsch, J.J. \& Yasin, M.M. (1998). A framework for benchmarking in the public sector. International Journal of Public Sector Management, 11 (2/3), 91-115.

Elefalk, K. (2001). The Balanced Scorecard of the Swedish Police Service: 7000 officers in total quality management project. Total Quality Management, 12 (7), 958-966.

Golden-Biddle, K. \& Locke, K. (1993). Appealing work: An investigation of how ethnographic texts convince?. Organization Science, 4 (4), 595-616.

Higgins, P., James, P. \& Roper, I. (2004). Best value: Is it delivering?. Public Money \& Management, 24 (4), 251-258.

Hines, R.D. (1988). Financial accounting: in communicating reality, we construct reality. Accounting, Organizations and Society, 13 (3), 251-261.

Hinton, M., Francis, G. \& Holloway, J. (2000). Best practice benchmarking in the UK. Benchmarking: An International Journal, 7 (1), 52-61.

Hood, C. (1995). The 'New Public Management' in the 1980s: variations on a theme. Accounting, Organizations and Society, 20 (2/3), 93-109.

Hood, C. \& Miller, P. (2009). Public service risks: what's distinctive and new?. Risk and Public Services. London School of Economics and Political Science and Oxford University, 2-3.

Hopper, T. \& Major, M. (2007). Extending institutional analysis through theoretical triangulation: regulation and activity based costing in Portuguese telecommunications. European Accounting Review, 16 (1), 59-97.

Hoque, Z. (2005). Securing institutional legitimacy or organizational effectiveness? A case examining the impact of public sector reform initiatives in an Australian local authority. The International Journal of Public Sector Management, 18 (4/5), 367.

Hyvönen, T., Järvinen, J., Pellinen, J. \& Rahko, T. (2009). Institutional Logics, ICT and Stability of Management Accounting. European Accounting Review, 18 (2), 241-275.

INE (2013), National Statistics Institute of Spain.

Irwin, D. (2002). Strategy mapping in the public sector. Long range planning, 35 (6), 637-647.

Johnsen, $\AA$. (2005). What does 25 years of experience tell us about the state of performance measurement in public policy and management?. Public Money \& Management, 25 (1), 917.

Jones, S. (2004). Improving local government performance: one step forward not two steps back. Public Money \& Management, 24 (1), 47-55.

Järvinen, J. (2006). Institutional Pressures for Adopting New Cost Accounting Systems in Finnish Hospitals: Two Longitudinal Case Studies. Financial Accountability \& Management, 22 (1), 21-46.

Kaplan, R.S. \& Norton, D.P. (1992). The Balanced Scorecard - Measures that drive performance. Harvard Business Review (January-February), 71-79.

Kaplan, R.S. (2001). Strategic performance measurement and management in nonprofit organizations. Nonprofit Management \& Leadership, 11 (3), 353-370.

Klingner, D.E. (2006). Building Global Public Management Governance Capacity: 'The Road Not Taken'. Public Administration Review, 66 (5), 775-779.

Kloot, L. (1997). Organizational learning and management control systems: responding to environmental change. Management Accounting Research, 8 (1), 47-73.

Kloot, L. \& Martin, J. (2000). Strategic performance management: a balanced approach to performance management issues in local government. Management Accounting Research, $11(2), 231-251$. 
Kurunmäki, L. (2004). A hybrid profession-the acquisition of management accounting expertise by medical professionals. Accounting, Organizations and Society, 29 (3-4), 327-347.

Lapsley, I. (2008). The NPM agenda: back to the future. Financial Accountability \& Management, 24 (1), 77-96.

Lapsley, I. (2009). New public management: the cruellest invention of the human spirit?. ABACUS, 45 (1), 1-21.

Law/Ley Orgánica del 27/1986, de 13 de Marzo, de Fuerzas y Cuerpos de Seguridad.

Light, P.C. (1997). Perspectives on performance measurement and public sector accounting; Organizational performance and measurement in the public sector: Toward service, effort, and accomplishment reporting; and measuring outcome in the public sector. Journal of Policy Analysis and Management, 16 (2), 328-333.

Lodge, M. \& Gill, D. (2011). Toward a new era of administrative reforms? The myth of postNPM in New Zealand. Governance: an International Journal of Policy, Administration, and Institutions, 24 (1), 141-166.

Lounsbury, M. (2008). Institutional rationality and practice variation: new directions in the institutional analysis of practice. Accounting, Organizations and Society, 33 (4-5), 349361.

Loveday, B. (2005). The challenge of Police Reform in England and Wales. Public Money \& Management, 25 (5), 275-281.

Lukka, K. (2007). Management accounting change and stability: loosely coupled rules and routines in action. Management Accounting Research, 18 (1), 76-101.

Malmi, T. \& Granlund, M. (2009). In search of management accounting theory. European Accounting Review, 18 (3), 597-620.

Marques, L., Ribeiro, J.A. \& Scapens, R.W. (2011). The use of management control mechanisms by public organizations with a network coordination role: A case study in the port industry. Management Accounting Research, 22 (4), 269-291.

McAdam, R. \& Walker, T. (2003). An inquiry into balanced scorecards within best value implementation in UK local government. Public Administration, 81 (4), 873-892.

McAteer, M. \& Orr, K. (2006). Public participation in Scottish local government: strategic and corporate confusions. Public Money \& Management, 26 (2), 131-138.

McLean, I., Haubrich, D. \& Gutiérrez-Romero, R. (2007). The Perils and Pitfalls of Performance Measurement: The CPA Regime for Local Authorities in England. Public Money \& Management, 27 (2), 111-118.

Meyer, J.W. \& Rowan, B. (1977). Institutionalized Organizations: Formal Structure as Myth and Ceremony. American Journal of Sociology, 83 (2), 340-363.

Meyer, J.W. (1996). Otherhood: The Promulgation and Transmission of Ideas in the Modern Organizational Environment. In Czarniawska, B. and Sevón, G. (Eds.) Translating organizational Change (De Gruyter \& Co., Berlin), 241-252.

Modell, S. (2004). Performance measurement myths in the public sector: a research note. Financial Accountability \& Management, 20 (1), 39-55.

Modell, S. (2009). Institutional research on performance measurement and management in the public sector accounting literature: a review and assessment. Financial Accountability \& Management, 25 (3), 277-303.

Moers, F. (2005). Discretion and bias in performance evaluation: the impact of diversity and subjectivity. Accounting, Organizations and Society, 30 (1), 67-80.

Muñoz, C.I.; Campos, M.; Urquía, E. \& Cano E. (2006). Hacia la convergencia de la información publicada por los entes locales. Revista Presupuesto y Gasto Público, 44, 145-176.

Navarro, A., Rodriguez, D.O. \& Hernández, A. (2008). Identifying barriers to the application of standardized performance indicators in local government. Public Management Review, 10 (2), 241-262. 
Noordegraaf, M. \& Abma, T. (2003). Management by measurement? Public management practices amidst ambiguity. Public Administration, 81 (4), 853-871.

Northcott, D. \& Llewellyn S. (2003). The 'ladder of success' in healthcare: the UK national reference costing index. Management Accounting Research, 14 (1), 51-66.

Norverto, C; Campos, M.; Muñoz, C.I. \& Zornoza, J. (2000). Indicadores para la gestión pública. Instituto de Estudios Fiscales.

Oliver, C. (1991). Strategic responses to institutional processes. Academy of Management Review, $16(1), 145-179$.

Oliver, C. (1992). The antecedents of deinstitutionalization. Organization Studies, 13 (4), 563588.

Olson, O., Guthrie, J. \& Humphrey, C. (1998). International experiences with 'new' public financial management (NPFM) reforms: New world? Small world? Better world?. In Olson, O., Guthrie, J. and Humphrey, C. (Eds.) Global Warning: Debating International Developments in New Public Financial Management, 17-48 (Oslo: Cappelen Akademisk Forlag).

Olson, O., Humphrey, C. \& Guthrie, J. (2001). Caught in an evaluatory trap: a dilemma for public services under NPFM. The European Accounting Review, 10 (3), 505-522.

Pollanen, R.M. (2005). Performance measurement in municipalities: Empirical evidence in Canadian context. International Journal of Public Sector Management, 18 (1), 4-24.

Power, M. (2004). The risk management of everything. The Journal of Risk Finance, 5 (3), 58 65.

Quinlivan, D. (2000). Rescaling the balanced scorecard for local government. Australian Journal of Public Administration, 59 (4), 36-41.

Radnor, Z. \& McGuire, M. (2004). Performance management in the public sector: fact or fiction?. International Journal of Productivity and Performance Management, 53 (3/4), 245-260.

Rashman, L. \& Radnor, Z. (2005). Learning to Improve: Approaches to Improving Local Government Services. Public Money \& Management, 25 (1), 19-26.

Rautiainen, A. \& Järvenpää, M. (2012). Institutional logics and responses to performance measurement systems. Financial Accountability \& Management, 28 (2), 164-188.

Reay, T. \& Hinings, C.R. (2009). Managing the rivalry of competing institutional logics. Organization Studies, 30 (6), 629-652.

Taylor, J. (2009). Strengthening the Link between Performance Measurement and Decision Making. Public Administration, 87 (4), 853-871.

ter Bogt, H., Budding, T., Groot, T. \& van Helden, J. (2010). Current NPM research: digging deeper and looking further. Financial Accountability \& Management, 26 (3), 241-245.

ter Bogt, H. \& Scapens, R.W. (2009). Performance Measurement in Universities: a Comparative Study of Two A\&F Groups in the Netherlands and the UK. SSRN working paper. (http://papers.ssrn.com/sol3/papers.cfm?abstract id=1432749).

Tessier, S. \& Otley, D. (2012). A conceptual development of Simon's Levers of Control framework. Management Accounting Research, 23 (3), 171-185.

Thornton, P. \& Ocasio, W. (1999). Institutional logics and the historical contingency of power in organizations: executive succession in the higher education publishing industry, 19581990. American Journal of Sociology, 105 (3), 801-843.

Tillema, S. (2010). Public sector benchmarking and performance improvement: what is the link and can it be improved?. Public Money \& Management, 30 (1), 69-75.

Tõnnisson, K. (2004). Impact of public sector reform initiatives on performance measurement. The perspective of Estonian local governments. EGPA 2004 Annual Conference, Ljubljana, Slovenia.

Torres, L., Pina, V. \& Yetano, A. (2011). Performance measurement in Spanish local government. A cross-case comparison study. Public Administration, 89, (3), 1081-1109. 
Urquía, E. \& Robleda, H. (2013). Guía sectorial para la implantación de un sistema integrado de costes e indicadores de gestión en la Policía Local. FEMP-Working Paper.

Vaivio, J. \& Sirén, A. (2010). Insights into method triangulation and paradigms in interpretive management accounting research. Management Accounting Research, 21 (2), 130-141.

Verbeeten, F. (2011). Public sector management practices in the Netherlands. International Journal of Public Sector Management, 24 (6), 492-506.

Vinnari, E. \& Näsi, S. (2008). Creative accrual accounting in the public sector: 'milking' water utilities to balance municipal budgets and accounts. Financial Accountability \& Management, 24 (2), 97-116.

Visitfinland (2014). Tourism in Finland - Key facts and figures. Finnish tourism year 2013. http://www.visitfinland.com/about-us/tourism-finland/ .

Wiesel, F., Modell, S. \& Moll, J. (2011). Customer orientation and management control in the public sector: a garbage can analysis. European Accounting Review, 20 (3), 551-581.

Wilson, J. (2004). Comprehensive performance assessment - Springboard or dead-weight?. Public Money \& Management, 24 (1), 63-68.

Wisniewski, M. \& Dickson, A. (2001). Measuring performance in Dumfries and Galloway Constabulary with the Balanced Scorecard. Journal of the Operational Research Society, $52(10), 1057-1066$.

Wittgenstein, L. (1963). Philosophical Investigations, Translated by G.E.M. Anscombe. Basil Blackwell. Oxford. UK.

Yin, R.K. (1984), Case study Research. Design and Methods. Sage. Newbury.

\section{APPENDIX List of the follow-up interviews}

Finland: 6 interviews in Autumn 2012; average interview time: 42 minutes.

1) Chief police officer, Central Finland police department, 54 minutes

2) Crime investigator, Central Finland police department, 26 minutes

3) Police officer, Central Finland police department, 45 minutes

4) Administrative officer, Central Finland police department, 53 minutes

5) Administrative officer, Eastern Finland police department, 52 minutes

6) Administrative secretary, Eastern Finland police department, 22 minutes.

Spain: 5 interviews in Autumn 2012; average interview time: 55 minutes.

1) Chief Manager of Police, Central Spain police department, 70 minutes

2) Administrative officer, Central Spain police department, 50 minutes

3) Police officer, Central Spain police department, 65 minutes

4) Chief police officer, Central Spain police department, 40 minutes

5) Administrative police, Central Spain police department, 50 minutes.

\section{Acknowledgements:}

The authors wish to thank Salvador Carmona, Markus Granlund, Robert Scapens, Louise Kloot, Roger Smith and the two anonymous reviewers for their most valuable comments and support. In addition we would like to thank the interviewees for their helpful answers. 